\title{
THE PHENOMENON OF REDUCED PLASTICITY IN LOW-ALLOYED COPPER
}

\author{
POJAV ZMANJŠANJA PLASTIČNOSTI MALO LEGIRANEGA \\ BAKRA
}

\section{Wojciech Ozgowicz¹, Elżbieta Kalinowska-Ozgowicz² ${ }^{2}$, Barbara Grzegorczyk ${ }^{1}$, Klaudiusz Lenik ${ }^{2}$}

${ }^{1}$ Silesian University of Technology, Mechanical Engineering Faculty, Institute of Engineering Materials and Biomaterials, Konarskiego Str. 18A, 44-100 Gliwice, Poland

${ }^{2}$ Lublin University of Technology, Fundamentals of Technology, Nadbystrzycka Str. 38, 20-618 Lublin, Poland kalinowska-ozgowicz@tlen.pl

Prejem rokopisa - received: 2015-05-19; sprejem za objavo - accepted for publication: 2015-10-12

doi:10.17222/mit.2015.101

\begin{abstract}
This paper presents the results of investigations that allow us to determine the influence of the temperature of plastic deformation in the range from $20{ }^{\circ} \mathrm{C}$ to $800{ }^{\circ} \mathrm{C}$ during static tensile tests on the mechanical properties and structure of low-alloy copper alloys of the type $\mathrm{CuCo} 2$ and $\mathrm{CuCo} 2 \mathrm{~B}$, completed by measurements of the microhardness and observations of the structure in a light microscope, and also of fractures in a scanning electron microscope. Based on the results of these investigations the temperature range for the occurrence of the reduced plasticity of the alloys $\mathrm{CuCo} 2$ and $\mathrm{CuCo} 2 \mathrm{~B}$ could be determined.

Keywords: low-alloy copper, plastic deformation, structure, mechanical properties, brittleness

Članek predstavlja rezultate preiskav, ki omogočajo opredelitev vpliva temperature na plastično deformacijo v območju od $20{ }^{\circ} \mathrm{C}$ do $800{ }^{\circ} \mathrm{C}$ s statičnimi nateznimi preizkusi na mehanske lastnosti in strukturo malo legiranih bakrovih zlitin, vrste CuCo2 in $\mathrm{CuCo} 2 \mathrm{~B}$, izvedenih $\mathrm{z}$ merjenjem mikrotrdote ter opazovanjem mikrostrukture $\mathrm{v}$ svetlobnem mikroskopu in prelomov $\mathrm{v}$ vrstičnem elektronskem mikroskopu. Na osnovi rezultatov teh preiskav je bilo mogoče opredeliti temperaturno področje pojava zmanjšanja plastičnosti zlitin vrste $\mathrm{CuCo} 2$ in $\mathrm{CuCo} 2 \mathrm{~B}$.

Ključne besede: malo legirani baker, plastična deformacija, struktura, mehanske lastnosti, krhkost
\end{abstract}

\section{INTRODUCTION}

Low-alloy copper is applied in various ways. However, most of it is applied in electrical engineering and electronics. It is also used in the production of welding electrodes, elements of bearings, non-sparking tools and chemical apparatus. ${ }^{1-3}$ High-temperature brittleness results in a reduced plasticity at the given temperature of deformation, called the temperature of minimum plasticity (TMP). ${ }^{4-6}$ The reason for this phenomenon concerning the brittleness of copper alloys has not been fully explained yet; it depends on many factors, mainly on the chemical composition, the structure of the alloy and the parameters of the deformation..$^{7-12}$

The purpose of the present investigations was to determine the influence of the temperature of deformation on the mechanical properties, the structure, and particularly the range of temperature for the reduced plasticity of low-alloy copper, containing cobalt and boron of the type $\mathrm{CuCo} 2$ and $\mathrm{CuCo} 2 \mathrm{~B}$.

\section{MATERIALS AND METHODS}

The investigations concerned low-alloy copper type $\mathrm{CuCo} 2$ and $\mathrm{CuCo} 2 \mathrm{~B}$ smelted in the laboratory in a crucible induction furnace with a frequency from $500 \mathrm{~Hz}$ to $4000 \mathrm{~Hz}$ and the mass of the charge up to $100 \mathrm{~kg}$. In the course of smelting to liquid the $\mathrm{CuCo} 2 \mathrm{~B}$ alloy, boron was added in an amount of $0.005 \%$. The ready melts were passed to a graphite gate with a diameter of $30 \mathrm{~mm}$. After cooling the obtained ingots, re-forged to rods, $15 \mathrm{~mm}$ in diameter, on a pneumatic forging hammer, the weight of its ram amounting to 200 t. For the chemical compositions of the investigated alloys $\mathrm{CuCo} 2$ and CuCo2B (Table 1).

Table 1: Chemical composition of the investigation alloys

Tabela 1: Kemijska sestava preiskovanih zlitin

\begin{tabular}{|c|c|c|c|c|c|c|c|}
\hline \multirow{2}{*}{$\begin{array}{c}\text { Alloy } \\
\text { type }\end{array}$} & \multicolumn{6}{|c|}{ Mass contents in mass fractions, $(w / \%)$} \\
\cline { 2 - 8 } & $\mathrm{Cu}+\mathrm{Ag}$ & $\mathrm{Co}$ & $\mathrm{Si}$ & $\mathrm{Fe}$ & $\mathrm{Ni}$ & $\mathrm{P}$ & $\mathrm{B}$ \\
\hline $\mathrm{CuCo} 2$ & 96.71 & 2.76 & 0.29 & 0.16 & 0.01 & 0.05 & - \\
\hline $\mathrm{CuCo} 2 \mathrm{~B}$ & 96.88 & 2.86 & 0.16 & 0.01 & 0.01 & 0.07 & 0.005 \\
\hline
\end{tabular}

After forging the rods were supersaturated at $900{ }^{\circ} \mathrm{C}$ and cooled in water. The temperature during this procedure was determined based on an analysis of a binary system of the phase equilibrium of copper with cobalt. ${ }^{11,12}$ The temperature of supersaturation was assumed to be $100{ }^{\circ} \mathrm{C}$ higher than the boundary temperature of the solubility of $\mathrm{Co}$ on $\mathrm{Cu}$ concerning the tested alloys. The 
operation of supersaturation was carried out in an electric chamber furnace equipped with a controller ensuring measurements of the temperature with an accuracy of $\pm 2{ }^{\circ} \mathrm{C}$. After their supersaturation the rods were cut into segments, from which samples were used for testing the mechanical properties, applying a threaded grip.

The chemical compositions of the alloys $\mathrm{CuCo} 2$ and $\mathrm{CuCo} 2 \mathrm{~B}$ were tested on monolithic samples in the shape of disks with a thickness of about $5 \mathrm{~mm}$ and a diameter of $30 \mathrm{~mm}$, cut out from the ingots.

The mechanical properties of the alloys $\mathrm{CuCo} 2$ and $\mathrm{CuCo} 2 \mathrm{~B}$ were tested on an Instron 1115 universal testing machine provided with a high-temperature resistance furnace, including a microprocessing system controlling the temperature. The procedure of heating was performed in a protective atmosphere containing $95 \%$ nitrogen and $5 \%$ hydrogen. Static tensile tests were accomplished in the temperature range $20{ }^{\circ} \mathrm{C}$ to $800{ }^{\circ} \mathrm{C}$ at a tensile rate of $20 \mathrm{~mm} / \mathrm{min}$, corresponding to the strain rate $\dot{\varepsilon}=1.2810^{-3} \mathrm{~s}^{-1}$. Based on the data on the curves of tension for the investigated alloys, the tensile strength $\left(R_{\mathrm{m}}\right)$ was determined, and the elongation $(A)$ and the reduction of the area of the sample $(Z)$ were calculated based on the geometrical features of the sample previous to and after the rupture. The result of the tests is the arithmetic mean of the three measurements.

Metallographic investigations were carried out on longitudinal microsections of the alloy $\mathrm{CuCo} 2$ and $\mathrm{CuCo} 2 \mathrm{~B}$ after supersaturation and hot tensile tests. The samples were immersed in self-hardening resin, and then mechanically polished. In order to reveal their structure the samples were etched in a reagent containing $5 \mathrm{~g}$ $\mathrm{FeCl}_{3}, 10 \mathrm{~cm}^{3} \mathrm{HCl}$ and $100 \mathrm{~cm}^{3} \mathrm{C}_{2} \mathrm{H}_{5} \mathrm{OH}$. Metallographic observations were performed using an Olympus GX71 (Japan) light microscope with a magnifying power of up to 1000 times. The size of the grains was measured by applying the method of sections.

Fractographic tests of the fractions after decohesion in the tensile test were produced by means of a DSM940 scanning electron microscope by the firm Opton, accomplished at an accelerating voltage of $20 \mathrm{kV}$ and magnifying power of up to 3000 times. The precipitation observed on the fractures was investigated by means of an EDAX X-ray microanalyzer. Prior to the fractographic test, the sample was ultra-sound cleaned in ethyl alcohol for $3 \mathrm{~min}$.

The microhardness was measured on a Vickers sclerometer, applying a load of $50 \mathrm{~g}$. These measurements were carried out on metallographic microsections of the alloys $\mathrm{CuCo} 2$ and $\mathrm{CuCo} 2 \mathrm{~B}$ after tension at a temperature of $20{ }^{\circ} \mathrm{C}$ to $800{ }^{\circ} \mathrm{C}$.

\section{RESULTS AND DISCUSSION}

The results of the analysis of the chemical compositions of the investigated alloys have been gathered in Table 1. The analysis revealed that in these alloys there is a presence of cobalt and boron, as well as admixtures of silicon, iron, nickel and phosphorus. These elements affect mainly the electrical conductivity of copper, reducing it. Moreover, cobalt and iron increase the hardness of these alloys, and phosphorus is a de-oxidant, increasing their viscosity.

The results of the static tensile tests allowed us to determine the effect of temperature on the strength and plastic properties of the alloys $\mathrm{CuCo} 2$ and $\mathrm{CuCo} 2 \mathrm{~B}$, and thus also to assess the range of temperature at which the plasticity of the investigated alloys decreases due to the dependence of elongation, contraction and strength on the temperature of deformation (Figures 1 to 3). Analyzing the dependence of the reduction of the area of the sample on the temperature of deformation of these alloys, it has been found to be more or less the same. In both these alloys the range of temperatures at which such a contraction attains its minimum value is quite evident.

The diagram of the dependence of elongation on the temperature of deformation of the alloy $\mathrm{CuCo} 2$ is characterized by a varying shape (Figure 1). At $20{ }^{\circ} \mathrm{C}$ the elongation of the alloy amounts to $34 \%$. An increase in the temperature of deformation is accompanied by a decrease in the value of $\mathrm{A}$, reaching its minimum of $4.7 \%$ at the temperature of $600{ }^{\circ} \mathrm{C}$. A further rise in the temperature of deformation to $800{ }^{\circ} \mathrm{C}$ involves an increase of the elongation to $22 \%$. At $20{ }^{\circ} \mathrm{C}$ the elongation of the alloy $\mathrm{CuCo}_{2} \mathrm{~B}$ amounts to $45.7 \%$. If the temperature of deformation rises from $20{ }^{\circ} \mathrm{C}$ to $550{ }^{\circ} \mathrm{C}$, the elongation decreases, reaching its minimum of $10 \%$ at $550{ }^{\circ} \mathrm{C}$. A further rise of the temperature of deformation results in an elongation amounting to $53 \%$ at $800{ }^{\circ} \mathrm{C}$. The alloy $\mathrm{CuCo} 2 \mathrm{~B}$ is characterized by a much larger elongation in the range of the temperature of deformation from $700{ }^{\circ} \mathrm{C}$ to $800{ }^{\circ} \mathrm{C}$ than the alloy $\mathrm{CuCo} 2$. Analyzing the dependence of the course of contraction on the temperature of deformation of the alloys $\mathrm{CuCo} 2$ and $\mathrm{CuCo} 2 \mathrm{~B}$, it has been found to be similar (Figure 2). In the case of both these alloys the range of temperature

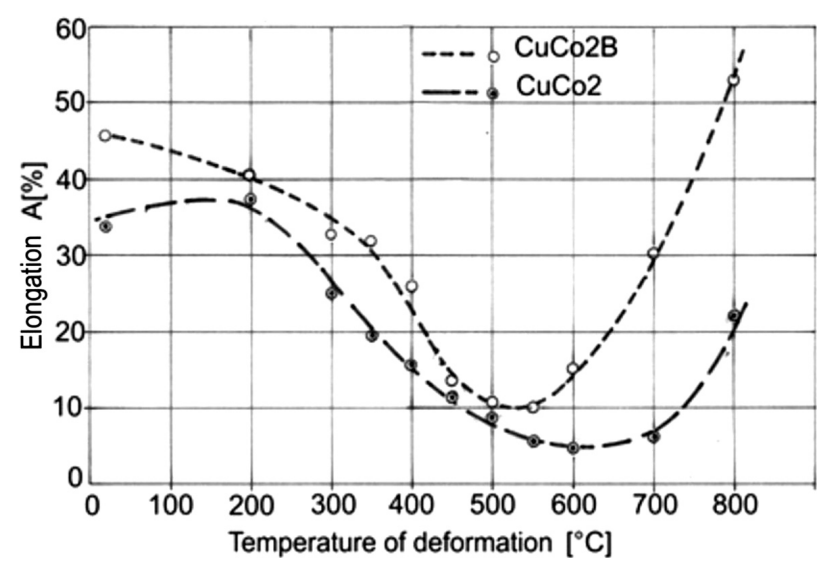

Figure 1: The influence of the temperature of plastic deformation in the tensile test on the elongation $(A)$ of the alloys $\mathrm{CuCo} 2$ and $\mathrm{CuCo} 2 \mathrm{~B}$ Slika 1: Vpliv temperature plastične deformacije pri nateznem preizkusu na raztezek $(A)$ zlitin $\mathrm{CuCo} 2$ in $\mathrm{CuCo} 2 \mathrm{~B}$ 


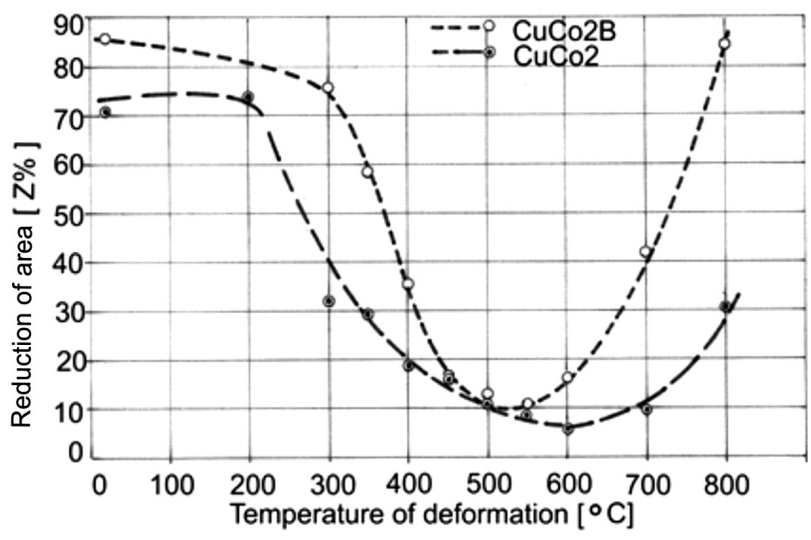

Figure 2: The influence of the temperature of plastic deformation in the tensile test on the reduction of area $(\mathrm{Z})$ of the alloys $\mathrm{CuCo} 2$ and $\mathrm{CuCo} 2 \mathrm{~B}$

Slika 2: Vpliv temperature plastične deformacije pri nateznem preizkusu na kontrakcijo $(Z)$ zlitin $\mathrm{CuCo} 2$ in $\mathrm{CuCo} 2 \mathrm{~B}$

characterized by a minimum contraction is quite distinct. The contraction of the alloy $\mathrm{CuCO}_{2}$, deformed in the range of temperature from $20{ }^{\circ} \mathrm{C}$ to $600{ }^{\circ} \mathrm{C}$, decreases, reaching its minimum at $600{ }^{\circ} \mathrm{C}(Z=5.5 \%)$. At a temperature of $600{ }^{\circ} \mathrm{C}$ to $800{ }^{\circ} \mathrm{C}$ the contraction increases up to a value of $30.6 \%$. At the temperature of deformation $20{ }^{\circ} \mathrm{C}$ the contraction of the alloy $\mathrm{CuCo} 2$ amounts to $71 \%$ (Figure 2).

On the curve of the dependence of the contraction on the temperature of deformation of the alloy $\mathrm{CuCo}_{2} \mathrm{~B}$ there occurs a local minimum (Figure 2). In the range of the temperature of deformation $20{ }^{\circ} \mathrm{C}$ to $550{ }^{\circ} \mathrm{C}$ the value of the contraction decreases from $85.7 \%$ at $20{ }^{\circ} \mathrm{C}$ and attains its minimum $Z=10.9 \%$ at $550{ }^{\circ} \mathrm{C}$. A further rise of the temperature of deformation (to $800{ }^{\circ} \mathrm{C}$ ) leads to an increase of the contraction to a value of $84.2 \%$.

Comparing the diagrams of the dependence of elongation and contraction on the temperature of deformation concerning the alloys $\mathrm{CuCo} 2$ and $\mathrm{CuCo} 2 \mathrm{~B}$, we find that in both cases there exists a range of temperature in which these alloys indicate a minimum of the plastic properties,

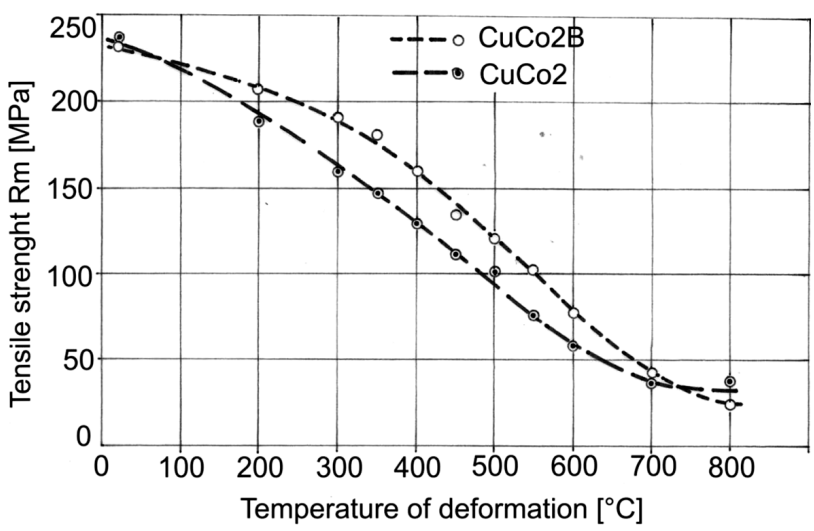

Figure 3: The influence of the temperature of plastic deformation in the tensile test on the strength $\left(R_{\mathrm{m}}\right)$ of the alloys $\mathrm{CuCo} 2$ and $\mathrm{CuCo} 2 \mathrm{~B}$ Slika 3: Vpliv temperature plastične deformacije pri nateznem preizkusu na trdnost $\left(R_{\mathrm{m}}\right)$ zlitin $\mathrm{CuCo} 2$ in $\mathrm{CuCo} 2 \mathrm{~B}$ characteristic for the phenomenon of brittleness (Figures 1 and 2). The alloy with the addition of boron is characterized by brittleness in the range of lower temperatures than the alloy without boron. The elongation and contraction of the alloy $\mathrm{CuCo}_{2} \mathrm{~B}$ exceed those of the alloy $\mathrm{CuCo} 2$ in the entire range of the investigated temperature. The alloy $\mathrm{CuCo} 2$ displays a minimum plasticity in the range of temperature from $500{ }^{\circ} \mathrm{C}$ to $700{ }^{\circ} \mathrm{C}$, and the alloy $\mathrm{CuCo} 2 \mathrm{~B}$ at a temperature of $450{ }^{\circ} \mathrm{C}$ to $600{ }^{\circ} \mathrm{C}$.

Subjected to a static tensile test in the range of temperature from $20{ }^{\circ} \mathrm{C}$ to $800{ }^{\circ} \mathrm{C}$, the investigated alloys display similar values of tensile strength (Figure 3). The curve in the diagram of the dependence of the tensile strength on the temperature of deformation concerning the alloys $\mathrm{CuCo} 2$ and $\mathrm{CuCo} 2 \mathrm{~B}$ is a decreasing function. The tensile strength of the alloy $\mathrm{CuCo} 2$, deformed at a temperature of $20{ }^{\circ} \mathrm{C}$ amounts to $237 \mathrm{MPa}$ and drops to $38 \mathrm{MPa}$ at $800{ }^{\circ} \mathrm{C}$, where as in the case of the alloy $\mathrm{CuCo} 2 \mathrm{~B}$ it amounts, respectively, to $232 \mathrm{MPa}$ and $34 \mathrm{MPa}$.

The results of the metallographic investigations allowed us to determine the influence of the temperature of deformation on the structure of the $\mathrm{CuCo} 2$ and $\mathrm{CuCo} 2 \mathrm{~B}$ in the range from $20{ }^{\circ} \mathrm{C}$ to $800{ }^{\circ} \mathrm{C}$ (Figures 4 to 9). After a hot tensile test the alloys $\mathrm{CuCO}_{2}$ and $\mathrm{CuCO}_{2} \mathrm{~B}$ have a variated structure in the zone of rupture and the central zone of the sample, with sliding bands. In the central part of the samples the grains have been found with a hardness of 71-93 HV and twins with straight and curve-linear boundaries. In the zone of rupture the structure of the alloy $\mathrm{CuCo} 2$, stretched at a temperature of $200{ }^{\circ} \mathrm{C}$, is characterized by the occurrence of microcracks at the boundaries of elongated grains of the phase $\alpha$ (Figure 4), and the central part of the sample by axial grains $\alpha$ with twins (Figure 5). The alloy $\mathrm{CuCo} 2 \mathrm{~B}$ has a similar structure in the zone of rupture. The structures of

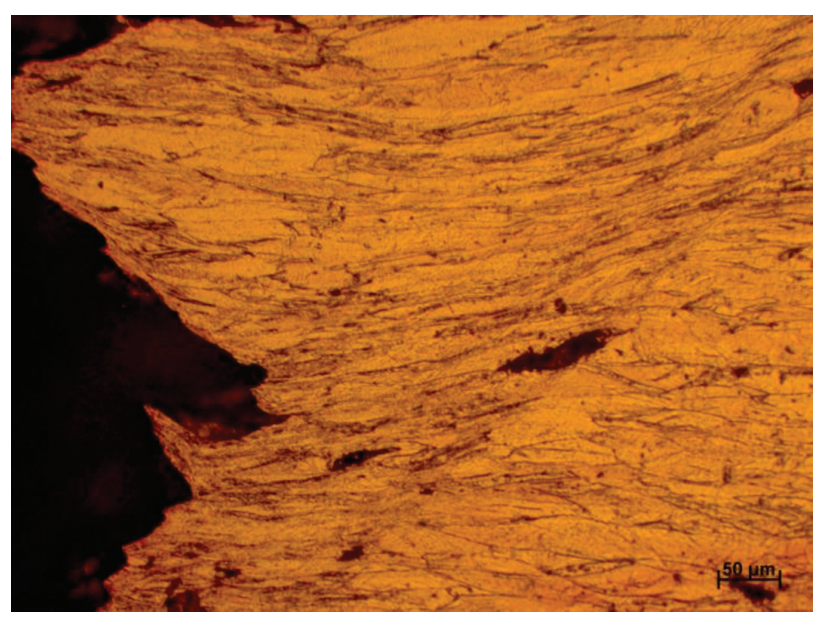

Figure 4: Elongated grains of the phase $\alpha$ with a micro-crack in the structure of the alloy $\mathrm{CuCo} 2$ after stretching at temperature of $200{ }^{\circ} \mathrm{C}$ (zone of rupture)

Slika 4: Razpotegnjena zrna $\alpha$ faze z mikrorazpokami v strukturi zlitine $\mathrm{CuCo} 2$, po nateznem preizkusu na temperaturi $200{ }^{\circ} \mathrm{C}$ (področje preloma) 


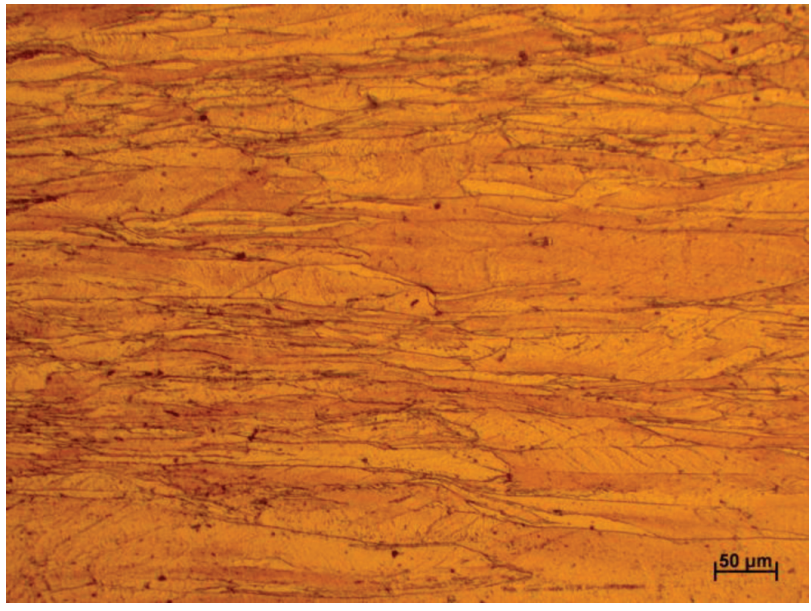

Figure 5: Elongated grains of the phase $\alpha$ with twins and bands of deformation in the structure of the alloy $\mathrm{CuCo} 2$ after stretching at a temperature of $200{ }^{\circ} \mathrm{C}$ (central zone)

Slika 5: Razpotegnjena zrna $\alpha$ faze z dvojčki in deformacijskimi pasovi v strukturi zlitine $\mathrm{CuCo} 2$ po nateznem preizkusu na temperaturi $200{ }^{\circ} \mathrm{C}$ (sredina vzorca)

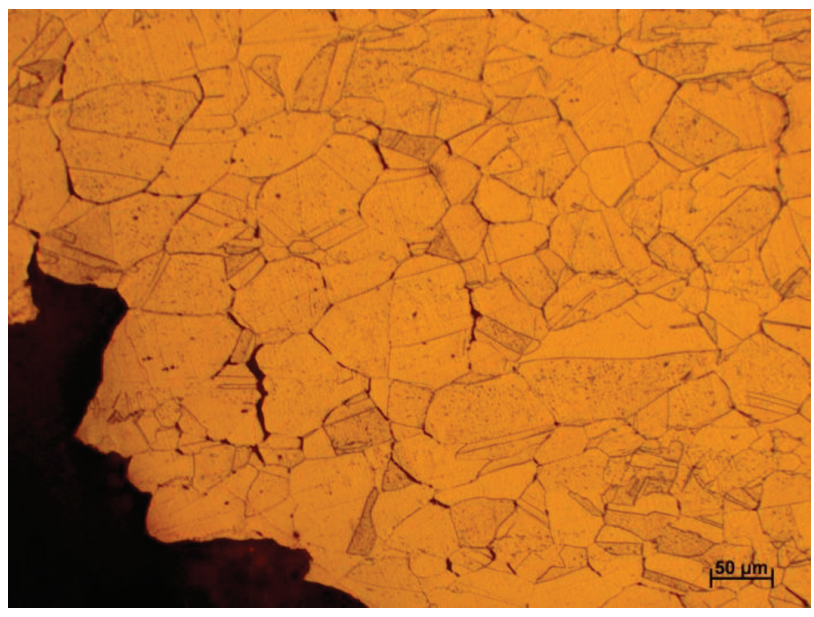

Figure 6: Recrystallized grains of the phase $\alpha$ and numerous cracks in the structure of the alloy $\mathrm{CuCo} 2 \mathrm{~B}$ after stretching at a temperature of $550{ }^{\circ} \mathrm{C}$ (zone of rupture)

Slika 6: Rekristalizirana zrna $\alpha$ faze in številne razpoke v struktur zlitine $\mathrm{CuCo} 2 \mathrm{~B}$ po nateznem preizkusu na temperaturi $550{ }^{\circ} \mathrm{C}$ (področje preloma)

alloys stretched at elevated temperatures display a larger amount of microcracks occurring at the boundaries of the grains and at the contact of three grains and twin boundaries in the zone of rupture. In the central part of the sample a heterogeous structure was detected consisting of a diversified size of the grains $(20 \mu \mathrm{m}$ to $60 \mu \mathrm{m})$ depending on the temperature of the deformation and due to the process of recrystallization.

In alloys stretched at the temperature of minimum plasticity $\left(550{ }^{\circ} \mathrm{C}\right)$ the structure in the zone of rupture is characterized by numerous micro-cracks. In the structure of the alloy $\mathrm{CuCo}_{2} \mathrm{~B}$, stretched at the temperature $550{ }^{\circ} \mathrm{C}$, the zone of rupture contains axial recrystallized grains of the phase $\alpha, 40 \mu \mathrm{m}$ in diameter, and also many microcracks (Figure 6). Also in the central part of the sample there are micro-cracks at the boundary of the phase $\alpha$ (Figure 7). The structure of this part of the sample contains grains of the phase $\alpha$ with many twins with straight-lined boundaries as well as stepped boundaries, testifying to the advanced recrystallization of the alloy. In the central part the sample of the alloy $\mathrm{CuCo} 2 \mathrm{~B}$ there are grains of the phase $\alpha$ with micro-cracks and precipitations. After their deformation at $600{ }^{\circ} \mathrm{C}$ the investigated alloys display the structure of grains of the phase $\alpha$, varying in their size, with twins and micro-cracks (Figures 8 and 9). The structure of the alloy $\mathrm{CuCo} 2 \mathrm{~B}$, elongated at a temperature of $800{ }^{\circ} \mathrm{C}$, displays numerous micro-cracks both in the zone of rupture and in the central part of the sample. In the structure of the central part of the sample the micro-cracks occurred in the front recrystallization due to the presence of large grains of the

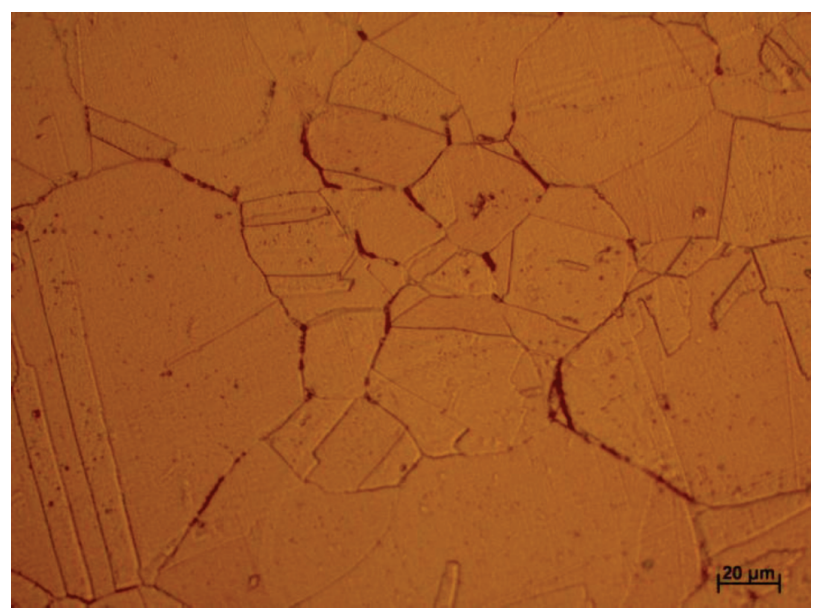

Figure 7: Micro-cracks at the boundaries of the phase $\alpha$ in the structure of the alloy $\mathrm{CuCo} 2 \mathrm{~B}$ after stretching at a temperature of $550{ }^{\circ} \mathrm{C}$ (central zone)

Slika 7: Mikrorazpoke na mejah $\alpha$ faze v strukturi zlitine $\mathrm{CuCo} 2 \mathrm{~B}$ po nateznem preizkusu na temperaturi $550{ }^{\circ} \mathrm{C}$ (sredina vzorca)

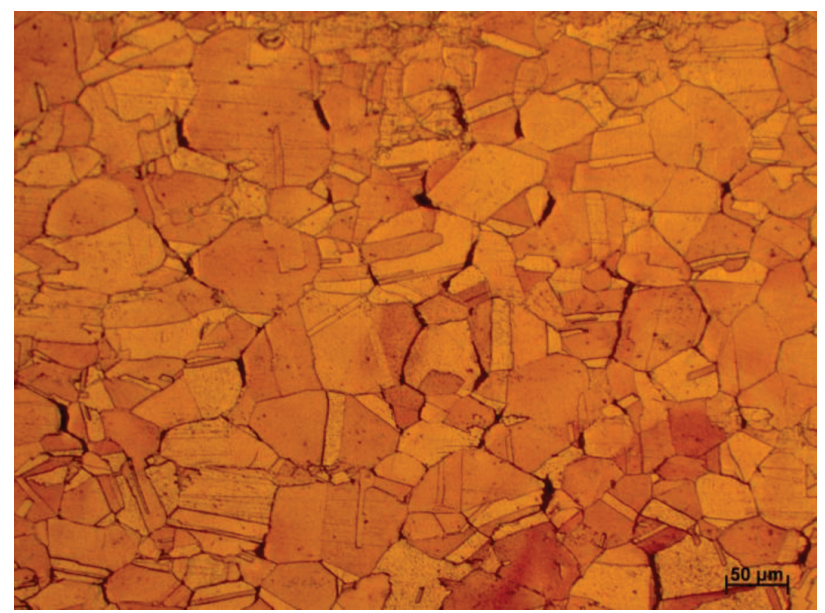

Figure 8: Differentiated grains of the phase $\alpha$ with the twins and micro-cracks in the structure of the alloy $\mathrm{CuCo} 2 \mathrm{~B}$ after stretching at the temperature $600{ }^{\circ} \mathrm{C}$ (central zone)

Slika 8: Diferencirana zrna $\alpha$ faze z dvojčki in mikrorazpokami v strukturi zlitine $\mathrm{CuCo} 2 \mathrm{~B}$ po nateznem preizkusu na temperaturi $600{ }^{\circ} \mathrm{C}$ (sredina vzorca) 


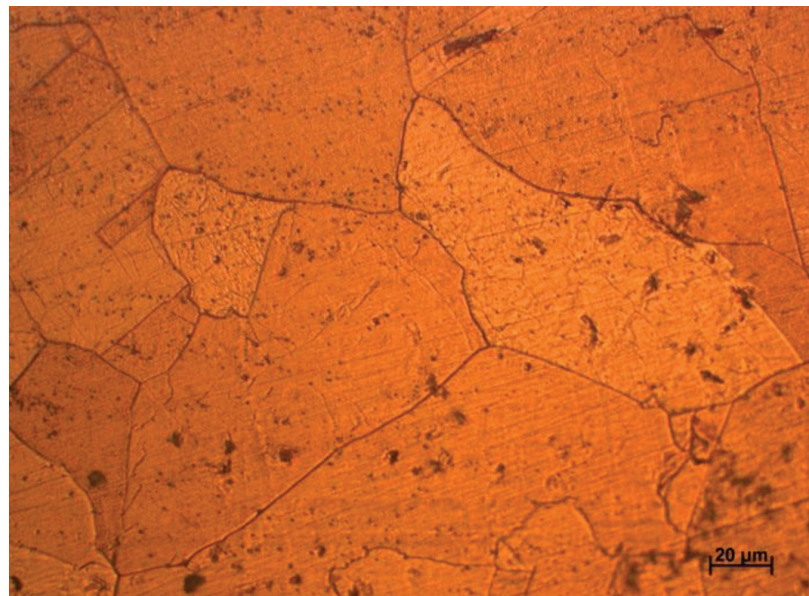

Figure 9: Coarse grains of the phase $\alpha$ with sub-grains in the structure of the alloy $\mathrm{CuCo} 2 \mathrm{~B}$ after stretching at a temperature of $800{ }^{\circ} \mathrm{C}$ (central zone)

Slika 9: Velika zrna $\alpha$ faze s podzrni v strukturi zlitine $\mathrm{CuCo} 2 \mathrm{~B}$ po nateznem preizkusu na temperaturi $800{ }^{\circ} \mathrm{C}$ (sredina vzorca)

phase (about $100 \mu \mathrm{m}$ ) with a hardness of about $60 \mathrm{HV}$ and a revealed substructure (Figure 9). The size of the grains in the phase $\alpha$ of the structure of the alloy $\mathrm{CuCo} 2 \mathrm{~B}$ results from the way of recrystallization in the course of and after the plastic deformation during the tensile test.

The results of fractographic investigations allowed us to determine the influence of the temperature of deformation on the character of the fractures of the alloys $\mathrm{CuCo} 2$ and $\mathrm{CuCo} 2 \mathrm{~B}$ after decohesion in the tensile test in the range of temperature from $20{ }^{\circ} \mathrm{C}$ to $800{ }^{\circ} \mathrm{C}$.

The fracture of the alloy $\mathrm{CuCo} 2$ and $\mathrm{CuCo} 2 \mathrm{~B}$ after the decohesion in the tensile test indicates a diversified character depending on the temperature of tension. At the temperature of deformation amounting to $200{ }^{\circ} \mathrm{C}$, the investigated alloys are characterized by a transcrystalline ductile fracture with numerous craters differing in the

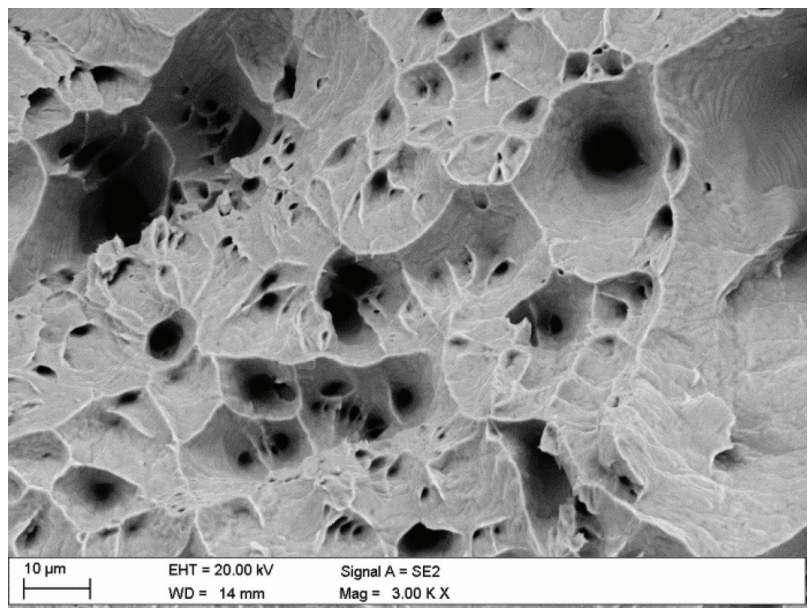

Figure 10: Transcrystalline ductile fracture in the alloy $\mathrm{CuCo} 2$ after a tensile test at $200{ }^{\circ} \mathrm{C}$

Slika 10: Transkristalni žilav prelom zlitine $\mathrm{CuCo} 2$ po nateznem preizkusu na $200{ }^{\circ} \mathrm{C}$

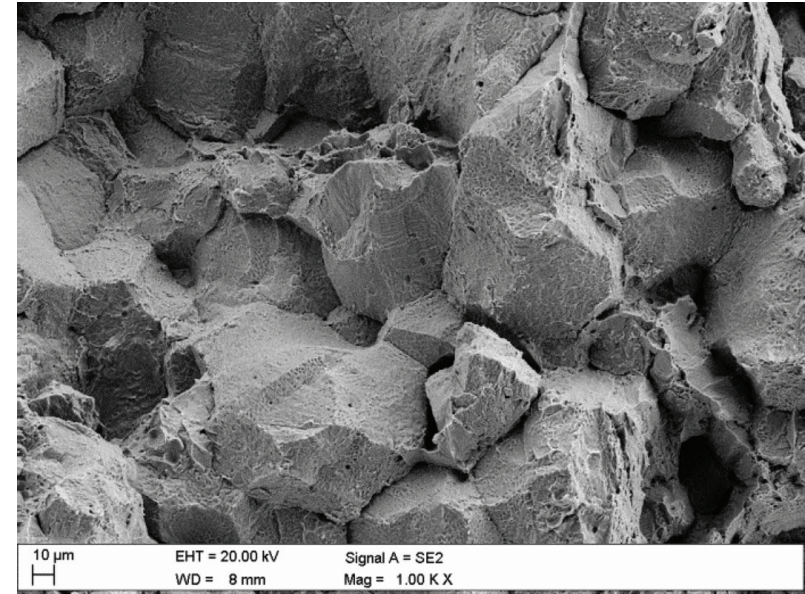

Figure 11: Intercrystalline brittle fracture in the alloy $\mathrm{CuCo} 2 \mathrm{~B}$ after a tensile test at $550{ }^{\circ} \mathrm{C}$

Slika 11: Interkristalni krhki prelom zlitine $\mathrm{CuCo} 2 \mathrm{~B}$, po nateznem preizkusu na $550{ }^{\circ} \mathrm{C}$

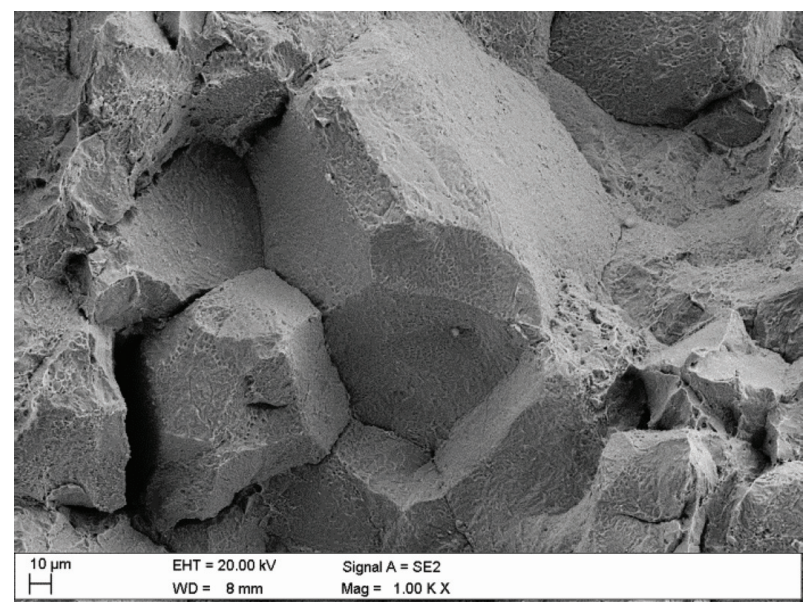

Figure 12: Intercrystalline brittle fracture in the alloy $\mathrm{CuCo} 2$ after a tensile test at $600{ }^{\circ} \mathrm{C}$

Slika 12: Interkristalni krhki prelom zlitine $\mathrm{CuCo} 2$ po nateznem preizkusu na $600{ }^{\circ} \mathrm{C}$

\begin{tabular}{|l|l|l|}
\hline Element & $\boldsymbol{W} \boldsymbol{t} \%$ & \multicolumn{1}{|c|}{$\mathbf{A} \%$} \\
\hline CoK & 03.30 & 03.55 \\
\hline CuK & 96.70 & 96.45 \\
\hline Matrix & Correction & ZAF \\
\hline
\end{tabular}

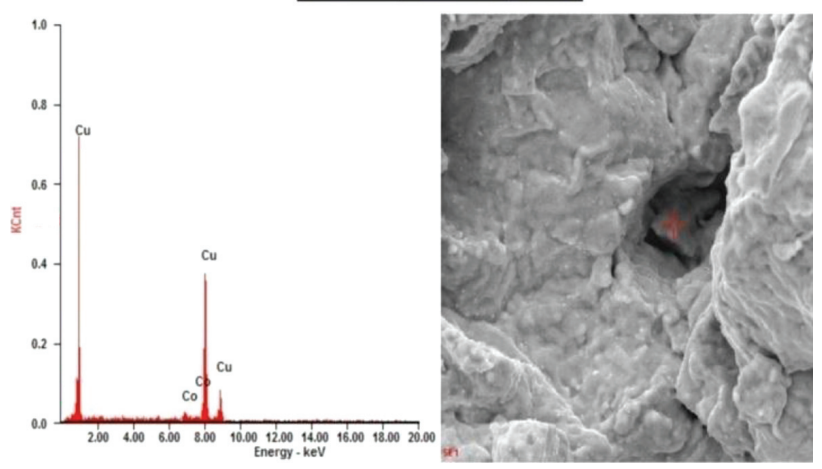

Figure 13: Result of the quantitative microanalysis of the chemical composition of a precipitate in the alloy $\mathrm{CuCo} 2$ after a tensile test at $550{ }^{\circ} \mathrm{C}$

Slika 13: Rezultati kvantitativne mikroanalize kemijske sestave izločka v zlitini $\mathrm{CuCo} 2$ po nateznem preizkusu na $550{ }^{\circ} \mathrm{C}$ 
diameters and precipitations in the bottom (Figure 10). The lateral planes of the craters are considerably corrugated.

At the temperature of deformation amounting to $550{ }^{\circ} \mathrm{C}$ and $600{ }^{\circ} \mathrm{C}$, these alloys display brittle intercrystalline fractures with many micro-cracks and precipitations (Figures 11 and 12).

The planes of the cracks indicate the effects of plastic deformation. At the bottom of the crater on the fracture of the alloy $\mathrm{CuCo} 2$ precipitations were found, the chemical composition of which was determined by means of an X-ray analysis (EDAX) and proved to contain $96.55 \%$ copper and $3.55 \%$ cobalt (Figure 13). In the alloy $\mathrm{CuCo} 2$ deformed at $600{ }^{\circ} \mathrm{C}$; an inter-crystalline brittle fracture was detected with micro-cracks at the boundaries (Figure 12), whereas in samples deformed at $800{ }^{\circ} \mathrm{C}$ a fracture mixed with cracks on the grain boundaries was observed.

\section{CONCLUSIONS}

The performed investigations and analyses of the obtained results allow us to draw the following conclusions:

1. The low-alloy copper type $\mathrm{CuCo} 2$ reaches its minimum plasticity in the tensile test at a temperature of deformation from $500{ }^{\circ} \mathrm{C}$ to $700{ }^{\circ} \mathrm{C}$, whereas in the case of the alloy $\mathrm{CuCo} 2 \mathrm{~B}$ the minimum value is attained at a temperature of $450{ }^{\circ} \mathrm{C}$ to $600{ }^{\circ} \mathrm{C}$.

2. An increase in the temperature of plastic deformation from $20{ }^{\circ} \mathrm{C}$ to $800{ }^{\circ} \mathrm{C}$ involves a decrease in the tensile strength of the alloy $\mathrm{CuCo} 2$ from about 240 $\mathrm{MPa}$ to about $40 \mathrm{MPa}$, and that of the alloy $\mathrm{CuCo} 2 \mathrm{~B}$ from about $230 \mathrm{MPa}$ to about $25 \mathrm{MPa}$.

3. The temperature of the minimum plasticity (TMP) of the alloy $\mathrm{CuCo} 2 \mathrm{~B}$ from $20{ }^{\circ} \mathrm{C}$ to $800{ }^{\circ} \mathrm{C}$ is about 50 ${ }^{\circ} \mathrm{C}$ lower than the TMP of the alloy $\mathrm{CuCo} 2$. With a microaddition of boron the alloy is also more plastic ( $A$ and $Z$ by about $5 \%$ ) in the range of TMP if compared with the alloy $\mathrm{CuCO}_{2}$.

4. The structures of the investigated alloys of copper in the range TMP are characterized by homogeneous grains in the solution $\alpha$, about $40 \mu \mathrm{m}$ in size, with numerous micro-cracks at the grain boundaries.
5. The investigated plastically hot-deformed low-alloys beyond the region TMP have a typical structure of the solution $\alpha$ with a differing degree of deformation or dynamic or static recrystallization and a ductile fracture.

6. Low-alloy copper, in the range of TMP characterized by minimum plastic properties ( $A$ and $Z$ about $5-10$ $\%)$, displays after stretching a brittle intercrystalline fracture.

7. A micro-addition of boron involves increased plastic properties of the alloy $\mathrm{CuCo} 2 \mathrm{~B}$ in the entire range of the temperature of plastic deformation and changes the character of the fracture in the temperature interval from $550{ }^{\circ} \mathrm{C}$ to $800{ }^{\circ} \mathrm{C}$.

\section{REFERENCES}

${ }^{1}$ M. Tokarski, An outline of physical metallurgy of metals and non-ferrous alloys, Silesian Publishing House, Katowice 1986

${ }^{2}$ Z. Górny, I. Sobczak, Modern casting materials based on non-ferrous, ZA-PIS Publishing House, Kraków 2005

${ }^{3}$ K. Kurski, Copper and its technical alloys, Silesian Publishing House, Katowice 1967

${ }^{4}$ W. Ozgowicz, Physico-chemical, structural and mechanical factor of intergranular brittleness, PhD Thesis, Silesian University of Technology, Gliwice, Poland 2004

${ }^{5}$ R. Nowosielski, Explication of minimum plasticity effect of mono-phase brasses, Mechanika, PhD Thesis, Silesian University of Technology, Gliwice, Poland 2000

${ }^{6}$ W. Ozgowicz, E. Kosek, Computer simulation of the diffusive segregation of impurities on the grain boundaries of metallic poly-crystals, Archive Science of Materials, 2 (2004), 93-112

${ }^{7}$ A. Maciejny, Brittleness of metals, Silesian Publishing House, Katowice 1973

${ }^{8}$ W. Ozgowicz, Structure and properties of copper and phosphorus tin bronzes zirconium modified in the process of hot deformation, Ore and Non-Ferrous Metals, 3 (1995), 96-103

${ }^{9}$ W. Ozgowicz, Analysis of intergranular embrittlement mechanisms of $\alpha$-bronzes at elevated temperature, Part 1, Ores and Non-Ferrous Metals, 6 (2005), 320-327

${ }^{10} \mathrm{~W}$. Ozgowicz, Analysis of intergranular embrittlement mechanisms of $\alpha$-bronzes at elevated temperature, Part 2, Ores and Non-Ferrous Metals, 7 (2005), 377-391

${ }^{11}$ B. Massalski, Binary alloy phase diagrams, ASM, 1990

${ }^{12}$ W. Loskiewicz, M. Orman, Equilibrium of binary metal alloys, PWN Publishing House, Warszawa 1956 